\title{
FORMULASI MASKER EKSTRAK DAUN PEPAYA (CARICA PAPAYA L.) SEBAGAI ANTI JERAWAT
}

\author{
Intan Pratiwi, Youstiana Dwi Rusita \\ Kementerian Kesehatan Politeknik Kesehatan Surakarta Jurusan Jamu \\ Diterima : 15 Agustus 2018, Disetujui : 27 Agustus 2018
}

\begin{abstract}
Background: Mask is one of the effective facial skin cleanser. Mask has merit as deep cleansing,it's cleaning the dirt on the skin layer deeper, binds skin cells that have died, refine pores of the skin, clean the remnants of excess fat on the surface of the skin's face, reduce skin irritation, smoothing layer outer skin and nourish the skin, so it looks bright. This study uses papaya leaf extract has a content of the enzyme papain, alkaloids, pseudokapain, glikosid, karposid and saponins. Alkaloid contained in papaya leaves is a kind karpain which has anti bacterial activity. The advantages of the mask is the method of production can be prepared in a simple way. Masks in this study is made in the form of powder to make it easier to use and storage. Method: This study have purpose to determine the results of mask powder formulation of papaya leaf extract as an anti acne that meet the test parameters include physical, organoleptic test, water content test, $p H$ test, and flow rate of irritation test. Result: This research is experimental observation. The results of organoleptic test mask bone-white powder, scented roses and soft textured, the results of water content of $7.5 \%$, a flow rate of over 9 seconds, $p H$ of 6.35. Conclusion: The results of irritation test to the 20 volunteers did not show any reaction of irritation
\end{abstract}

Keywords: Mask Formulation, Leaf Extract Papaya, Anti-acne

\section{PENDAHULUAN}

Masker wajah adalah pasta krim (gel) yang diterapkan pada wajah setelah dibersihkan. Masker sering mengandung mineral, vitamin, dan protein. Masker wajah dapat dihilangkan dengan membilas wajah dengan air atau menyeka wajah dengan kain lembab hingga bersih (Aceng R. F \& Rina Nurmarlina, 2012). Masker memiliki manfaat sebagai deep cleansing, yaitu membersihkan kotoran yang menempel pada lapisan kulit yang lebih dalam, mengikat sel-sel kulit yang telah mati, memperbaiki pori-pori kulit, membersihkan sisa-sisa kelebihan lemak pada permukaan kulit, mengurangi iritasi kulit, memberikan kenyamanan pada kulit, menghaluskan lapisan luar kulit, dan memberi nutrisi sehingga kulit terlihat cerah (Harry, 2000). Daun pepaya memiliki komponen Flavonoid dan vitamin $\mathrm{C}$ yang lebih tinggi dibandingkan dengan daun jambu biji. Diduga yang memiliki komposisi Flavonoid dan $\mathrm{C}$ yang tinggi akan lebih cepat memberi penyembuhan jerawat dibandingkan dengan yang memiliki komposisi Flavonoid dan vitamin $\mathrm{C}$ yang lebih rendah. Proses penyembuhan jerawat meliputi pengurangan reaksi radang yaitu benjolan berwarna merah dapat berkurang setelah dilakukan perawatan secara baik dan zat-zat aktif yang dibutuhkan telah meresap ke dalam kulit secara sempurna. Beberapa penelitian sebelumnya meneliti tentang formulasi sediaan masker peel off 
dari ekstrak daun papaya dan penelitian yang lainnya mengenai perbedaan hasil pengurangan jerawat dengan menggunakan masker daun pepaya dan daun jambu biji oleh Wulandari, Maya (2014) dengan hasil pengurangan jerawat pada kulit wajah yang menggunakan masker daun pepaya sangat baik, yaitu dalam masker pepaya lebih besar 47 S.I(standar internasional) dibandingkan dengan masker daun jambu biji yang memiliki 25 S.I (standar internasional).

Formulasi masker ekstrak daun papaya pada penelitian ini menggunakan bahan-bahan yang aman untuk kulit. Meskipun demikian uji keamanan merupakan salah satu syarat sebelum bahan baku atau produk akhir dapat dijual ke masyarakat umum. Pengujian efek iritasi kulit dari bahan baku atau produk akhir merupakan elemen penting dari prosedur keamanan (Robinson dan Perkins, 2002). Masker dengan bahan alami saat ini lebih disukai oleh masyarakat umum terutama bagi para wanita karena lebih alami dan tidak ada efek samping yang serius dari dampak penggunaan masker, dibandingkan dengan masker yang telah dicampur dengan bahan kimia. Tujuan lain dari penggunaan masker tradisional adalah lebih efisien dan ekonomis (Virgita, V.M, 2015)

Berdasarkan uraian di atas maka peneliti tertarik untuk melakukan penelitian mengenai pembuatan masker serbuk ekstrak daun pepaya dan dalam pembuatannya perlu dilakukan uji fisik yang meliputi uji organoleptis, uji waktu alir, uji $\mathrm{Ph}$, uji kadar air dan uji iritasi

\section{METODE PENELITIAN}

Alat dan Bahan Penelitian yaitu serbuk daun pepaya, etanol $70 \%$, Amylum oryzae, Amylum maydis,
Kaolin, asam benzoat, Oleum rosae, plester (hypafix), kertas saring, aluminium foil, kapas,Timbangan analitik, beker glass, batang pengaduk, gelas ukur, cawan, penjepit, waterbath, rotary evaporator, mortir, stamfer, ayakan mesh 16 , oven.

Penelitian ini termasuk penelitian observasi eksperimental karena peneliti membuat dan mengamati sejumlah hasil uji meliputi uji organoleptis, uji kecepatan alir, uji $\mathrm{pH}$, uji kadar air dan uji iritasi masker serbuk daun papaya. Penelitian ini membutuhkan Ethical Clearance (EC) didapat dari Komisi Etik Penelitian Kesehatan RSUD Dr.Moewardi, karena penelitian ini yang menggunakan makhluk hidup sebagai subyek penelitian. Subjek penelitian adalah Responden yang digunakan untuk uji iritasi sebanyak 20 orang teknik patch test yaitu tempel terbuka selama 3 hari. Data yang dihasilkan dalam bentuk narasi, teks, tabel tanpa pengujian statistik.

\section{HASIL PENELITIAN}

Ekstraksi dilakukan dengan metode maserasi. 100 gram serbuk daun pepaya diekstraksi dengan menggunakan 1 liter pelarut etanol $70 \%$ selama 5 hari dan dilanjutkan dengan remaserasi dilakukan terhadap ampas selama 2 hari. Maserat yang diperoleh kemudian diuapkan pelarutnya menggunakan rotary evaporator pada suhu $50^{\circ} \mathrm{C}$ dilanjutkan dengan penguapan di atas waterbath suhu $50^{\circ} \mathrm{C}$ hingga diperoleh ekstrak kental. Selanjutnya dilakukan uji ekstrak daun papaya. 
Tabel 1. Hasil Uji Ekstrak Daun Pepaya

\begin{tabular}{lll}
\hline No. & \multicolumn{1}{c}{$\begin{array}{c}\text { Hasil Uji Ekstrak Daun } \\
\text { Pepaya }\end{array}$} & \multicolumn{1}{c}{ Hasil } \\
\hline 1. & Kadar Air & $3,45 \%$ \\
2. & Uji pH & 5,08 \\
3. & Bebas Alkohol & Tidak ada bau \\
& & khas ester dari \\
& & alcohol \\
4. & Uji Alkaloid & $\checkmark$ Reagen \\
& & Wagner \\
& & (hasil positif \\
& & berwarna \\
& & coklat) \\
& & $\checkmark$ Reagen \\
& & Dragendroff \\
& & (hasil positif \\
& & Endapan \\
& & Coklat \\
& & Kemerahan)
\end{tabular}

Pembuatan masker ekstrak daun pepaya terdiri dari zat aktif ekstrak daun pepaya dan zat tambahan dicampurkan hingga homogen. Kemudian dilanjutkan dengan uji fisik sesuai dengan hasil pada tabel 2.

Tabel 2. Hasil Uji Fisik Masker Serbuk

\begin{tabular}{|c|c|c|}
\hline No. & $\begin{array}{l}\text { Hasil Uji Fisik Masker } \\
\text { Serbuk }\end{array}$ & Hasil \\
\hline \multirow[t]{4}{*}{1.} & Uji Organoleptis & \\
\hline & a. Warna & Putih Tulang \\
\hline & b. Aroma & Mawar \\
\hline & c. Tekstur & Lembut \\
\hline 2. & Uji pH & 6,35 \\
\hline 3. & Uji Kadar Air & $7,5 \%$ \\
\hline 4. & Uji Kecepatan Alir & 9 detik \\
\hline
\end{tabular}

sesuai dengan kriteria inklusi yaitu bersedia menjadi responden, sedangkan kriteri eksklusinya yaitu responden yang mempunyai riwayat alergi. Pengujian dilakukan terhadap 20 orang relawan dengan teknik patch test yaitu tempel terbuka yang dilakukan dengan mengoleskan sediaan masker seluas 2,5 $\mathrm{cm}$ pada lengan atas sukarelawan. Uji keamanan dilakukan selama 24 jam, 48 jam dan 72 jam. Area uji diperiksa dan diamati adanya perubahan sebagai reaksi kulit.

Tabel 3. Hasil Uji Iritasi Responden

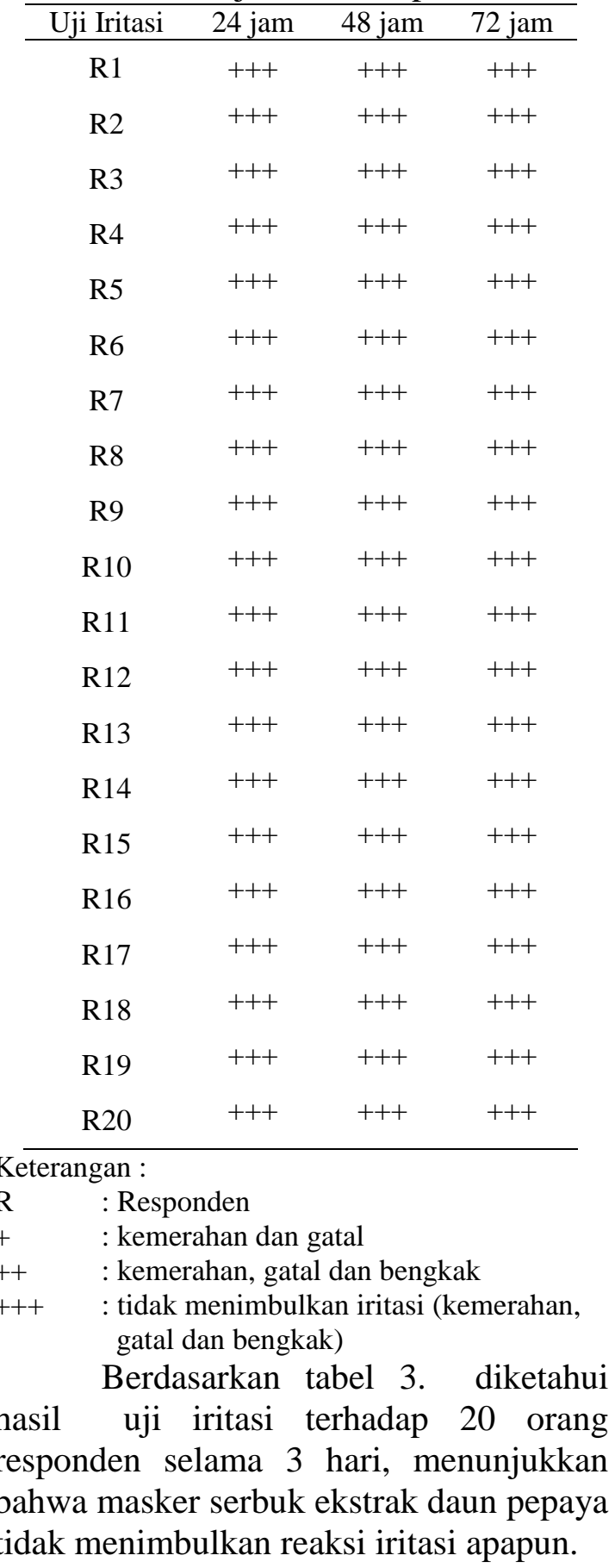




\section{PEMBAHASAN}

Pada pembuatan sediaan masker serbuk ekstrak daun papaya perlu dilakukan pengujian awal yaitu saat dalam bentuk ekstrak meliputi uji organoleptik, uji kadar air, uji pH, uji kecepatan alir dan uji iritasi.

Uji organoleptik Dilakukan dengan cara mengamati warna, aroma dan tekstur dari sediaan masker yang telah dibuat. Masker serbuk ekstrak daun pepaya dalam penelitian ini bertekstur lembut, beraroma mawar dan berwarna putih tulang. Beraroma mawar karena ada penambahan Oleum rosae yang bertujuan untuk menutupi aroma khas dari daun pepaya, masker serbuk berwarna putih tulang karena ekstrak daun pepaya yang telah dipanaskan berwarna kuning kehijauan ditambahkan dengan bahan-bahan lain yang berwarna putih dan telah dilakukan pengeringan sehingga warna masker serbuk menjadi putih tulang. Penelitian lain menyatakan bahwa aroma dan warna masker tergantung dari bahan yang digunakan dalam pembuatan masker (Jumarani, 2009; Fauzi, 2012). Sedangkan untuk Ekstrak daunpepaya dalam penelitian ini bertekstur kental, beraroma khas daun pepaya dan berwarna kuning kehijauan.

Hasil uji kadar air pada masker serbuk ekstrak daun pepaya menunjukkan 7,5\% dan kadar air ekstrak daun pepaya adalah 3,45 \%, hal ini telah sesuai ketentuan kadar air yang terkandung dalam suatu bahan yaitu $\leq 10 \%$ (Anonim, 2008). Menurut Anonim dalam Feri (2006) kadar air yang >10\% akan menyebabkan terjadinya proses enzimatik dan kerusakan oleh mikroba.

Uji pH dilakukan karena merupakan salah satu faktor yang dapat mempengaruhi terjadinya iritasi pada kulit. Kulit normal berkisar antara $\mathrm{pH} 4,5-$ 6,5. Nilai $\mathrm{pH}$ yang melampaui 7 dikhawatirkan dapat menyebabkan iritasi kulit (Gozali, 2009). Hasil uji pH pada ekstrak serbuk pepaya yaitu 5,01 hal tersebut aman untuk digunakan. Penelitian yang dilakukan oleh Mayawati dkk, 2014 menyatakan bahwa sediaan yang mempunyai $\mathrm{pH}$ terlalu asam dapat menyebabkan iritasi pada kulit, sedangkan untuk pH yang terlalu basa dapat menyebabkan kulit menjadi kering.

Uji kecepatan alir dengan hasil masker serbuk ekstrak daun pepaya dalam penelitian ini mengalir dalam 9 detik, maka telah sesuai ketentuan pengujian serbuk yaitu mengalirkan 100 gram $\leq 10$ detik (Anshory, 2007). Sifat alir ini penting untuk dievaluasi karena berperan penting dalam keseragaman bobot ataupun homogenitas komposisi masker. Hasil penelitian pengujian waktu alir serbuk telah sesuai dengan penelitian Burhan L dkk (2012) yang menunjukkan bahwa uji kecepatan alir berkisar antara 8,2 sampai 9,7 detik.

Pada uji iritasi pada 20 orang panelis memberikan hasil bahwa sediaan masker yang dibuat tidak menimbulkan reaksi apapun baik kemerahan (eritema) dan pembengkakan (edema) maupun panas, gatal-gatal atau perih. Menurut Wasitaatmadja (1997), uji iritasi kulit dilakukan untuk mencegah terjadinya efek samping terhadap kulit. Hasil uji iritasi terhadap kulit sukarelawan di atas menunjukkan bahwa semua sukarelawan memberikan hasil negatif terhadap parameter reaksi iritasi, Sehingga sediaan masker serbuk dari ekstrak daun pepaya aman untuk digunakan sebagai sediaan topical. 


\section{KESIMPULAN DAN SARAN}

Hasil uji kadar air masker serbuk ekstrak daun pepaya sebesar 7,5\%.Hasil uji Kecepatan alir masker serbuk ekstrak daun pepaya selama 9 detik.Hasil uji Derajat keasaman $(\mathrm{pH})$ masker serbuk ekstrak daun pepaya sebesar 6,35.Hasil Uji Organoleptis masker serbuk berwarna putih tulang, beraroma mawar, dan bertekstur lembut.Hasil uji iritasi menunjukkan bahwa sediaan masker serbuk ekstrak Daun Pepaya tidak menimbulkan iritasi (kemerahan, gatal dan bengkak). Saran untuk penelitian selanjutnya yaitu sebaiknya dilakukan uji stabilitas pada berbagai sediaan dan aktifitas antioksidan dan uji efektifitas pada masker serbuk ekstrak daun Pepaya pada bakteri Propionibacterium Acnes, serta dilakukan uji hedonik.

\section{DAFTAR RUJUKAN}

Anonim, 2008, Farmakope Herbal Indonesia, Edisi 1,Departemen Kesehatan Republik Indonesia, Jakarta.

Anonim. 1979. Farmakope Indonesia. Edisi Ketiga. Jakarta: Penerbit DepartemenKesehatan RI

Anshory, H., Syukri, Y., dan Malasari, Y. 2007. Formulasi Tablet EffervescentDari Ekstrak Ginseng Jawa (Tlinum paniculatum) Dengan Variasi Kadar Pemanis Aspartam. Jurnal IlmiahFarmasi . Vol 4 No.I.

Burhan, L., Paulina, V., \& Hamidah, S., 2012. Formulasi Sediaan Granul Effervescent Sari Buah Sirsak (Annona muricata L). Jurnal UNSRAT Pharmacon. 1(2): 72-78

Fauzi, Aceng Ridwan dan Nurmalina, Rina. 2012. Merawat Kulit dan
Wajah. Jakarta: PT Elex Media Komputindo

Feri, M. 2006. Pengaruh cara pengeringan terhadap mutu simplisia sambiloto. Balai Penelitian Tanaman Obat dan Aromatik. Bul. Littro. Vol XVII No. 1. Hal 1-5.

Gozali, D., Abdassah, M., Subghan, A., Dan Al-Lathiefah, S. 2009. Formulasi Krim Pelembab Wajah yang Mengandung Tabir Surya Nanopartikel Zink Oksida Salut Silikon. Bandung Farmaka, 7(1): 37-46.

Harry, Ralph G. 2000. Harry Cosmeticology. New York: Chemical Publishing

Jumarani, Louis. 2008.The Essence of Indonesia SPA.Jakarta : Gramedia Pustaka Utama

Mayawati, E., Pratiwi, L., \& Wijianto, B., 2014. Uji Efektifitas Antioksidan Ekstrak Metanol Buah Pepaya (Carica papaya L.) dalam Formulasi Krim. Jurnal Mahasiswa Farmasi Fakultas Kedokteran dan Ilmu Kesehatan UNTAN. 1(1): 1-11

Poucher, W.A. Howard G.M . 1979. Perfums, Cosmetics and Soaps. Volume 3.Modern cosmetics. Seven edition. London : chapman and hill.

Robinson, M.K and M.A. Perkins. 2002. A Strategy for Skin Irritation Testing. American Journal of Contact Dermatitis, Vol 13, No 1.

Virgita, V.M. 2015. Pemanfaatan Ketan Hitam Sebagai Masker Wajah. Skripsi : Jurusan Pendidikan Kesejahteraan Keluaga Fakultas Teknik Universitas Negeri Semarang. 
Wasitaatmadja, S. M. 1997. Penuntun Ilmu Kosmetik Medik. Jakarta: Penerbit Universitas Indonesia.

Wulandari, Maya. 2014. Perbedaan Hasil Pengurangan Jerawat Dengan Menggunakan Masker Daun Pepaya Dan Masker Daun Jambu Biji. Jurnal Tata Rias, Volume 6 nomor $6: 11-14$ 